Provided for non-commercial research and education use. Not for reproduction, distribution or commercial use.

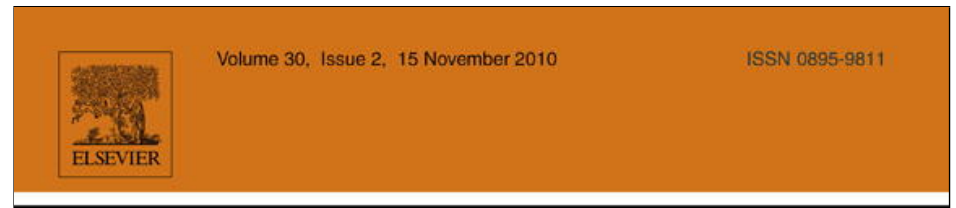

Journal of

South American Earth Sciences

Including Mexico, Central America, The Caribbean and the Antarctic Peninsula

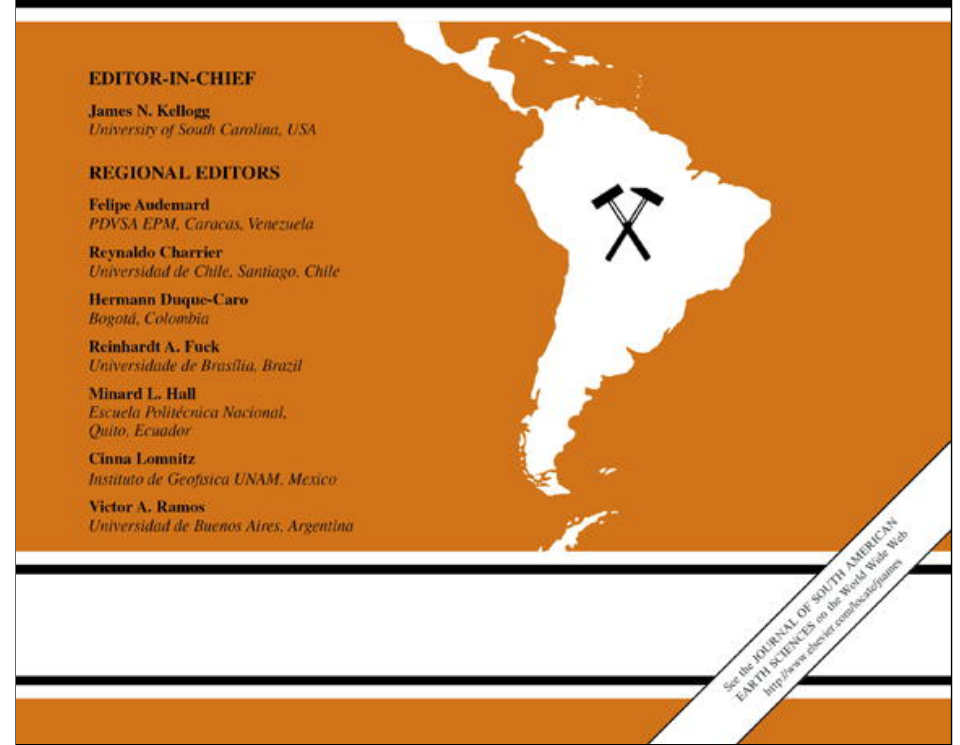

This article appeared in a journal published by Elsevier. The attached copy is furnished to the author for internal non-commercial research and education use, including for instruction at the authors institution and sharing with colleagues.

Other uses, including reproduction and distribution, or selling or licensing copies, or posting to personal, institutional or third party websites are prohibited.

In most cases authors are permitted to post their version of the article (e.g. in Word or Tex form) to their personal website or institutional repository. Authors requiring further information regarding Elsevier's archiving and manuscript policies are encouraged to visit:

http://www.elsevier.com/copyright 


\title{
South Georgia and Gondwana's Pacific Margin: Lost in translation?
}

\author{
Graeme Eagles* \\ Department of Earth Sciences, Royal Holloway University of London, Egham, Surrey TW20 OEX, United Kingdom
}

\section{A R T I C L E I N F O}

\section{Article history:}

Received 2 February 2010

Accepted 20 April 2010

\section{Keywords:}

South Georgia

Extended continental margin

Tectonic reconstruction

Antarctic circumpolar current

Gondwana

Ophiolite

\begin{abstract}
A B S T R A C T
The geology of South Georgia has long been interpreted as the product of processes acting at the Pacific margin of Gondwana in Jurassic and earlier times. This placement requires $1600 \mathrm{~km}$ of translation of South Georgia to its present location, for half of which there is no evidence. Assuming this means that $800 \mathrm{~km}$ of the translation cannot have occurred, it requires that those processes acted at a location much further east, within the interior of Gondwana. One such location could have been at the southern edge of the Deseado Terrane, which collided and sutured with Gondwana in Carboniferous times. Later, in this location, South Georgia would have experienced shearing and extension during the earliest stages of breakup of the supercontinent, eventually to form part of the ensuing ocean's northern margin. These, or possibly more recent tectonic events on the lengthening northern margin of the Scotia Sea, led to the northward obduction of ophiolitic rocks onto the island. A history like this reduces South Georgia to a peripheral role in the paleoceanographic development of Drake Passage, and strengthens the case for Eocene connection between the Pacific and Atlantic oceans.
\end{abstract}

(c) 2010 Elsevier Ltd. All rights reserved.

\section{Introduction}

Our knowledge of the effect of plate kinematics on the paleogeography of the South Georgia microcontinent is a key uncertainty in what is known of the tectonic development of Drake Passage, the ocean interchange at the southernmost extremity of South America. The opening of Drake Passage, in turn, may be of crucial importance for understanding the causes and effects of global change through Cenozoic times. In late-onset scenarios for Pacificto-Atlantic exchange through the passage the microcontinent is depicted traversing the Scotia Sea during Oligocene and Miocene times from an original position southeast of Tierra del Fuego (e.g. Barker et al., 1991). By hindering deep water connectivity along the way until 22-17 Ma (Barker, 2001), South Georgia could have played a role in Miocene changes to Antarctic glaciation by acting as the physical arbiter on the onset of Antarctic circumpolar oceanic circulation. This circulation has been suggested as necessary for the onset of continental-scale glaciation of Antarctica, which brought with it a range of global changes (Kennett et al., 1975). Early-onset alternatives leave South Georgia closer to its present-day position, permitting shallow Pacific-to-Atlantic water exchange to play a role in fundamentally changing oceanic circulation patterns in such a way that carbon sequestration sites shifted offshore at around $50 \mathrm{Ma}$, a change that is suggested to have initiated the long

\footnotetext{
* Tel.: +44 1784 443890; fax: +441784 471780

E-mail address: g.eagles@es.rhul.ac.uk.
}

Cenozoic decline in atmospheric $\mathrm{CO}_{2}$ concentration, and with it global temperature (Eagles et al., 2006).

\section{Tectonostratigraphy}

Well justified arguments concerning the original position of South Georgia are therefore very important. Although it can be traced back well over 50 years, the modern basis of the idea that South Georgia originated immediately southeast of Tierra del Fuego is in close tectonostratigraphic similarities between the two areas, which by now are separated from west to east by $1600 \mathrm{~km}$ (Fig. 1). Although the similarities are strong, it should be noted they are not prescriptive as they are also shared with the majority of the southern Patagonian Andes (Katz, 1963; Kraemer and Riccardi, 1997; Stern and de Wit, 2003; Calderón et al., 2007). The continental basement in both areas consists of pre mid-Jurassic metasedimentary rocks from accretionary settings (Dalziel and Elliot, 1971; Dalziel et al., 1975; Dalziel, 1982; Storey et al., 1977). Both areas host Jurassic to early Cretaceous ophiolites, with MORB signatures typical of mantle that was very slightly affected by subduction in the furthest north and west, and more strongly by transform faulting in South Georgia (Alabaster and Storey, 1990; Stern, 1991). The ophiolites and neighbouring intruded basement terranes form the floors of basins that are filled with Jurassic and early Cretaceous volcaniclastic aprons or deepsea fans that are dominated by andesitic and rhyolitic lithic debris (Winn, 1978; Storey and Macdonald, 1984). In Tierra del Fuego the sediments were derived from a volcanic arc terrane situated SW of the 


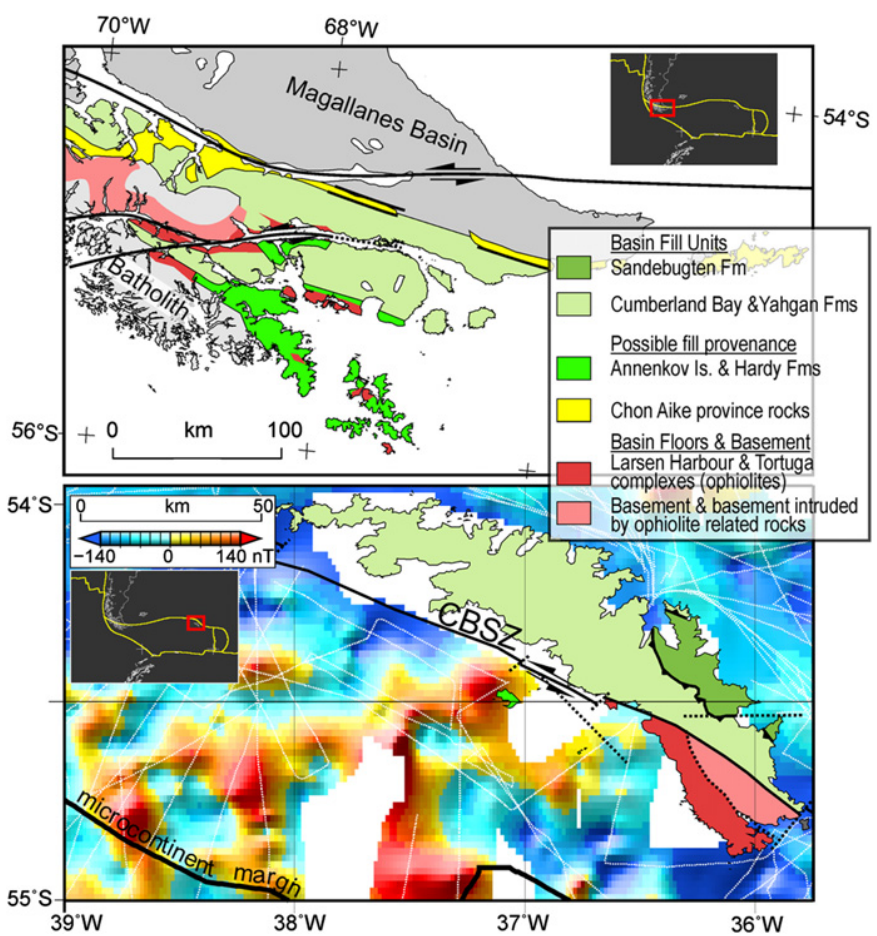

Fig. 1. Geology of part of Tierra del Fuego (top) and South Georgia (bottom), after Stern and de Wit (2003) and Storey and Macdonald (1984). Background to South Georgia map: magnetic anomalies (gridded from data recorded along the white dotted lines and reduced to the pole to minimize phase effects) from the compilation of Eagles et al. (2005). Batholith: igneous rocks formed at the Pacific margin following the deactivation of the Rocas Verdes Basin. CBSZ: Cooper Bay Shear Zone.

basin (Bruhn, 1979). On South Georgia, the Cumberland Bay Formation sediments were derived from an intermediate volcanic source to the SE, where minor occurrences of andesitic rocks are to be found in the Annenkov Island Formation, whereas the Sandebugten Formation was derived from the NE, in which direction there is currently no obvious source for the formation's prominent component of silicic volcaniclastic debris (Dalziel et al., 1975). In both locations the basins have undergone tectonic inversion involving the action of thrust and left-lateral strike-slip faults, tight asymmetrical folding along WNWoriented axes and the development of a strong slaty cleavage, resulting in greenschist facies metamorphism (Winn, 1978).

\section{Plate kinematics}

The standard interpretation of these relationships is that the two sequences formed neighbouring parts of a marginal basin at the Pacific margin of Gondwana (Dalziel et al., 1975), usually referred to as the Rocas Verdes Basin, which was filled by sediment shed from a volcanic arc on its Pacific flank and silicic volcanic fields on the opposing flank (Winn, 1978). After the basin was deactivated and shortened (Dalziel, 1981) it was dissected at the eastern end of Tierra del Fuego and its parts on South Georgia were transported eastwards to their present position, $1600 \mathrm{~km}$ away on the eastern end of the continental submarine North Scotia Ridge. About half of this transport can readily be explained as the result of seafloor spreading in the west Scotia Sea ( $30-6 \mathrm{Ma})$, which when undone restores South Georgia to a position close to $45^{\circ} \mathrm{W}$ on the ridge (Eagles et al., 2005). The remaining $800 \mathrm{~km}$ of displacement have been suggested to have occurred either shortly before or in accompaniment to this spreading by one of two routes (Fig. 2). Route $A$ involves transcurrent displacement along the North Scotia Ridge, as the continuation of a zone of strike-slip faulting that starts

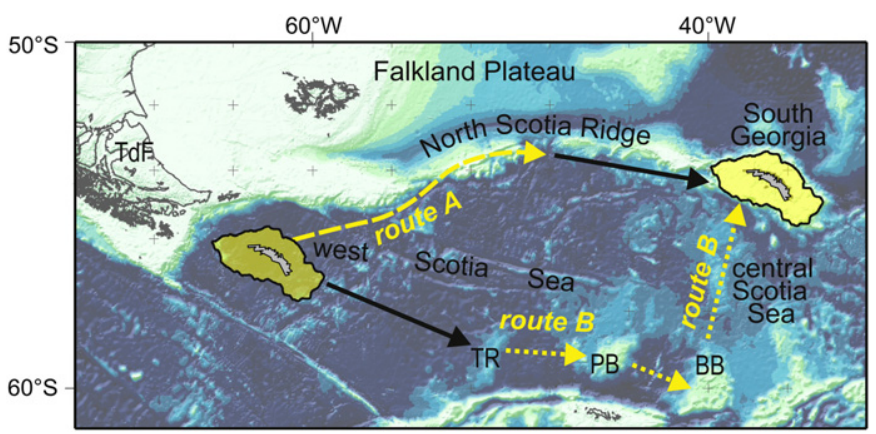

Fig. 2. Different routes (yellow arrows) for South Georgia to take from a Jurassic position near Tierra del Fuego, to its modern one on the North Scotia Ridge. Black arrows: component of route taken up by spreading in west Scotia Sea. BB: Bruce Bank, PB: Pirie Bank, TdF: Tierra del Fuego, TR: Terror Rise. (For interpretation of the references to colour in this figure legend, the reader is referred to the web version of this article.)

in Tierra del Fuego; this displacement is often related to the process of oroclinal bending that produced the pronounced eastwards bend of the Fuegian Andes (Cunningham et al., 1995). Route $B$ uses a combination of additional east-west and north-south directed seafloor spreading within basins at the margins of the west Scotia Sea (Barker et al., 1991).

Seismic and acoustic imaging of the North Scotia Ridge and Malvinas Basin reveal evidence for modest $(\sim 100 \mathrm{~km})$ left-lateral transcurrent motion since Pliocene times (Ludwig and Rabinowitz, 1982; Cunningham et al., 1998; Tassone et al., 2008). While there is evidence for strike-slip deformation in Eocene and Cretaceous times as well, this also seems to have been slight, as it is strongly outweighed by the evidence for contemporaneous convergence that accompanied the development of the Magallanes fold and thrust belt (e.g. Tassone et al., 2008). Similarly, the presence of active strike-slip faults is well documented on land in Tierra del Fuego, but field relations and anisotropy of magnetic susceptibility data suggest only tens of kilometres of transcurrent motion along them; in the face of this the region's widely-documented large paleomagnetic rotations, which are also often attributed to oroclinal bending, are more plausibly related to shortening and tilting (Menichetti et al., 2008; Maffione et al., 2009). Fig. 2 also shows that the transcurrent motion in route $A$ would have been achieved along faults striking approximately $\mathrm{NE}$, an orientation that is neither common in strike-slip faults onshore in Tierra del Fuego nor easily interpretable from marine geophysical analyses of the North Scotia Ridge (Fig. 1; Cunningham, 1995; Cunningham et al., 1998; Eagles et al., 2005; Glasser and Ghiglione, 2009). In summary, neither the hundreds of kilometres of transcurrent motion required to transport South Georgia to its present position by route $A$, nor the overall context for this motion in oroclinal bending, can be supported on the basis of currently available evidence.

The recognition of those problems with route $A$ gave rise to the suggestion that South Georgia's translation occurred on the eastern margins of two small oceanic basins in southern Drake Passage, either accompanying or preceding $400 \mathrm{~km}$ of northward plate motion towards and into collision with the Falkland Plateau as a result of Neogene seafloor spreading in the central Scotia Sea (e.g. Barker et al., 1991; Fig. 2, route $B$ ). This poses a problem for the Pacific margin placement of South Georgia by inserting the continental blocks of Terror Rise, Pirie and Bruce banks between it and Tierra del Fuego (Eagles et al., 2006). Regardless of whether or not this problem might be absorbed or accepted as a detail, route $B$ has other difficulties that make it untenable. Given the east-west oriented framework of Neogene major plate motions, north-south directed back-arc spreading in the central Scotia Sea can only have 
been possible if the ridge in the basin were coupled to rollback of a trench formed at a south directed subduction zone consuming South American oceanic lithosphere beneath South Georgia (Barker et al., 1991). There is no trace of the Neogene volcanism on South Georgia that would have resulted from this proposed subduction. Furthermore, there is no evidence in seismic, sidescan sonar, or bathymetry data sets for convergence or subduction in the Falkland Trough north of South Georgia (Ludwig and Rabinowitz, 1982; Cunningham et al., 1998; Graham et al., 2008).

Presently-available plate kinematic evidence only therefore permits the conclusion that South Georgia occupied more-or-less the same position on the North Scotia Ridge in Jurassic times that it did in Oligocene times, before seafloor spreading created the west Scotia Sea. On its own, this does not preclude a Jurassic position for South Georgia on the Pacific margin of Gondwana, having been moved from there by the process of true oroclinal bending (regional folding about a vertical axis) but it clearly cannot explain South Georgia's separation from Tierra del Fuego (Cunningham et al., 1995). Worse still, however, paleomagnetic data equivocate on the idea of oroclinal bending by any means in the southern Andes, at least since the opening of the Rocas Verdes Basin, and suggest that the process if it occurred at all probably only affected the region marginward of the basin (e.g. Burns et al., 1980; Kraemer, 2003; Ghiglione and Cristallini, 2007; Maffione et al., 2009). Right now, for South Georgia, it seems safest to conclude that oroclinal bending processes are neither a suitable explanation for a Jurassic Pacific margin placement nor for a placement neighbouring Tierra del Fuego.

\section{South Georgia in Gondwana}

The debate on oroclinal bending would be irrelevant in this context if South Georgia's tectonostratigraphy could reasonably be explained in the location implied by retaining it within the Oligocene geometry of the North Scotia Ridge at all earlier times. Made using these constraints, Fig. 3 shows a reconstruction to the times immediately before any of the movements between east and west Gondwana that were recorded in new seafloor, by employing the closed circuit of major plate rotations described by Eagles and Vaughan (2009), which are based on the orientations of fracture zones and magnetic anomaly data in the Weddell Sea (e.g. Ghidella et al., 2002). The only addition to that work shown here is to simplistically and illustratively include Graham Land in a position immediately to the west of Patagonia. While this kind of placement is frequently used in reconstructions, there is disagreement on how far north the overlap may have continued, and Fig. 3 is not intended to make a definitive statement on this issue (e.g. Barron et al., 1978; Calderón et al., 2007; Hervé et al., 2003, 2005). Instead, together with the following, I use Fig. 3 to detail how the known tectonostratigraphic elements of South Georgia can indeed be explained as the result of processes acting in such a location.

\subsection{Basement}

Outcrops at Black and Shag Rocks on the North Scotia Ridge, and drilling data in the Malvinas Basin, show that both areas share a similar pre-Jurassic metasedimentary basement with South Georgia and Tierra del Fuego (Dalziel and Elliot, 1971; Tassone et al., 2008). The basement of the Falkland Plateau, in contrast, consists of older, Proterozoic, metasediments intruded by granitoids that may be as young as Cambrian, exposed at Cape Meredith on the Falkland Islands, possibly also penetrated in DSDP hole 330 on Maurice Ewing Bank, and continuing west beneath the Deseado Massif to be referred to collectively as the Deseado Terrane (Pankhurst et al., 2006; Schilling et al., 2008). On the reconstruction, the basement metasediments of Tierra del Fuego, the North Scotia Ridge and South Georgia are depicted as
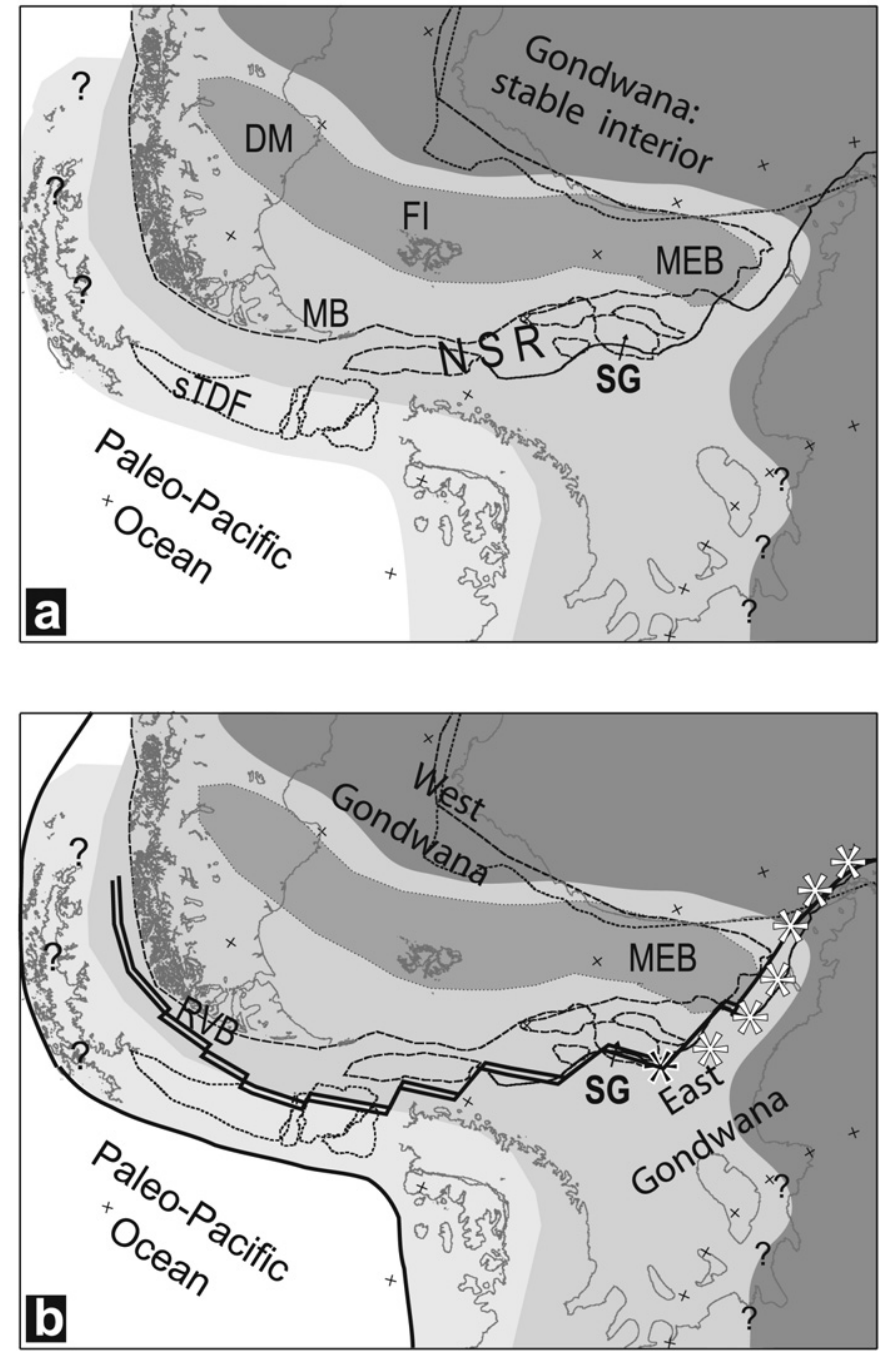

Fig. 3. Reconstructions of central West Gondwana before supercontinent breakup. a) showing the North Scotia Ridge as part of an autochthonous southern rim to the Deseado Terrane. b) showing how this rim may have subsequently been the site of initial breakup between east and west Gondwana. DM: Deseado Massif, FI: Falkland Islands, MEB: Maurice Ewing Bank, MB: Malvinas Basin, NSR: North Scotia Ridge, RVB: Rocas Verdes Basin, SG: South Georgia, sTDF: southern Tierra del Fuego, black asterisk: position of Polarstern Bank, white asterisks: Lebombo Monocline and Explora volcanic rifted margin.

a Paleozoic-aged autochthonous, probably accretionary, southern rim to the Deseado Terrane (Fig. 3a). Consistent with this view, detrital zircon compositions from Tierra del Fuego (Barbeau et al., 2009; Hervé et al., 2010) show that the Paleozoic metasediments there accumulated in sedimentological communication with the interior of Gondwana. Basement rocks in Graham Land may be similar (Millar et al., 2002), consistent with it forming a northwestern continuation of this rim as shown. The reconstruction thus suggests an S-shaped bend of the Pacific margin of Gondwana, which may be interpreted either as a primary remnant of the collision of the Deseado Terrane with Gondwana, or perhaps as the result of pre-Toarcian transcurrent motions between east and west Gondwana along the line of the supercontinent's eventual breakup.

\subsection{Basin floor}

Above its basement, drilling (Barker et al., 1977) and seismic data (Del Ben and Mallardi, 2004) around Maurice Ewing Bank reveal the upper reaches of a south-facing extended continental 
margin. A deeper, Jurassic, sequence is normally faulted, with the majority of faults dipping towards the south, and separated from shallower more smoothly layered sediments by a late Jurassic southward-dipping breakup unconformity. Lying $\sim 200 \mathrm{~km}$ to the south of this in Jurassic times, it would not be unreasonable for South Georgia to have occupied a more oceanward portion of the same margin (Fig. 3b). Consistent with this, the densely intruded Drygalski Fjord Complex is interpreted as representing a continent-ocean transition zone (Storey and Mair, 1982). From it, hornblendes in gabbro yield $\mathrm{K}-\mathrm{Ar}$ dates from around Gondwana breakup (201 $\pm 7 \mathrm{Ma}$ and $186 \pm 9 \mathrm{Ma}$; Tanner and Rex, 1979). $\mathrm{Ar}-\mathrm{Ar}$ and $\mathrm{U}-\mathrm{Pb}$ dating and trace element and Nd-isotope analyses on various elements of the Larsen Harbour Complex record how, by $150 \pm 1 \mathrm{Ma}$, this continent-ocean transition had evolved into an oceanic basin that contained long transform faults, suggesting a prominent role for shearing and consistent with the sedimentological evidence for the basin's narrowness (Dalziel et al., 1975; Alabaster and Storey, 1990; Mukasa and Dalziel, 1996). It is not necessary to invoke a marginal basin in this setting, as this mixture of movements was an expression of major plate motions between east and west Gondwana; they are mirrored on the conjugate margin in the Weddell Sea (Kristoffersen and Haugland, 1986) and are independently predicted by completion of the plate circuit in Gondwana (Eagles and Vaughan, 2009). Although their plate kinematic histories are less well constrained, the Rocas Verdes basinal remnants preserved further west in the Tortuga and Sarmiento complexes of Tierra del Fuego may represent more westerly reaches of the same boundary, given their similar ages (Mukasa and Dalziel, 1996; Calderón et al., 2007).

\subsection{Basin fill}

The source of the volcaniclastic detritus in South Georgia has been related to an arc terrane suggested to crop out as parts of the Annenkov Island Formation south of the main island (Storey and Tanner, 1982). There, magnetic data suggest the presence of a small number of point-like volcanic centres, but no wide, linear, ESE-striking, subduction-related arc (Fig. 1). Volcanic centres on this scale are explicable as parts of the Late Jurassic-Cretaceous Chon Aike silicic large igneous province, with its bimodal occurrences of rhyolites and andesites (Pankhurst and Rapela, 1995). Winn (1978) invoked rocks of the province in Tierra del Fuego as a viable source for the basin fill on South Georgia, but other occurrences, and hence other possible sediment sources, are widespread in Patagonia, the Antarctic Peninsula, and along the North Scotia Ridge (Pankhurst and Rapela, 1995; Pankhurst et al., 1998; Pandey et al., 2010). Consistent with paleocurrent measurements (Dalziel et al., 1975) and with the paleogeographical context introduced in Fig. 3, it is also possible to envisage an andesitic source related to that of Polarstern Bank, a large seamount near the SE margin of the Weddell Sea, and rhyolitic sources along the Lebombo monocline and its continuation at the Explora Escarpment, also in the Weddell Sea. Rhyolites are a prominent component of the Lebombo sequence (Riley et al., 2004), but the volcanic chemistry of Polarstern Bank is unknown.

\subsection{Deformation and ophiolite emplacement}

The Drygalski Fjord and Larsen Harbour complexes were tectonically emplaced along the Cooper Bay Shear Zone, a NW-trending mylonitized fault zone with a complicated history of normal, reverse, oblique and left-lateral strike-slip or transtensional deformation (Storey and Macdonald, 1984; Curtis, 2007; Curtis et al., 2010). Dalziel (1981) suggested that some of these movements occurred in mid-Cretaceous times on the basis of observations on rocks in South America that he assumed to be near neighbours to South Georgia's. Tanner and Rex (1979) suggest the timing of uplift coincided with a thermal event in the Drygalski Fjord Complex at 150-135 Ma, and Curtis et al. (2010) show that the Cooper Bay Shear Zone was indeed probably active some time between $160 \mathrm{Ma}$ and $84 \mathrm{Ma}$, and probably in a left-lateral transcurrent setting.

An alternative setting for the deformation invokes Eagles and Vaughan's (2009) 150 Ma plate boundary jump out of the southern Weddell Sea to South Georgia in response to anticlockwise rotation of plate divergence directions as the South Atlantic started to open, consistent with thermal resetting of Drygalski Fjord Complex rocks at 150-135 Ma (Tanner and Rex, 1979). Furthermore, if the Cooper Bay Shear Zone became reactivated as a segment of the South America-Antarctica plate boundary during such a jump, Eagles and Vaughan's (2009) Euler rotations show it should have expressed the changed plate motion vector, or a component of it, in a left-lateral transtensional sense. Entirely consistent with this, the majority of Curtis et al. (2010) fold appression data suggest a strong influence of transtension around the Cooper Bay Shear Zone early in its history.

Although significant passive uplift is feasible in such a latest Jurassic transtensional setting, as would be localised active uplift, the large apparent uplift and emplacement of the $\sim 40 \mathrm{~km}^{2}$ Drygalski Fjord-Larsen Harbour ophiolite on the Cooper Bay Shear Zone might more appropriately be ascribed to some later event with a convergent component. Marks and Stock's (2001) Euler rotations for the mid- to late Cretaceous Malvinas plate boundary suggest that, if it had a boundary with the South American plate at the Cooper Bay Shear Zone, this boundary would have been almost orthogonal and convergent; however those authors give good reasons for why the Malvinas-South America plate boundary may have been located further east. Alternatively, much later events may have been influential. Kristoffersen and LaBrecque (1991) attributed a broad regional uplift north of South Georgia, and indications of mild compressional reactivation of normal faults on the Northeast Georgia Rise, to Miocene convergence of the rise on the South American plate with South Georgia on the Scotia plate; it is possible that these events may also have involved uplift on the Cooper Bay Shear Zone. Similarly, Eagles et al. (2005) showed that the Cooper Bay Shear Zone would have represented a restraining bend to Oligocene left-lateral transcurrent motion between the central Scotia and South American plates. Pelayo and Wiens (1989) and Thomas et al. (2003) report on earthquakes that show late Cenozoic convergent processes continue today in the deep basin southwest of South Georgia.

\section{Summary \& Paleoceanographical implications}

In spite of its tectonostratigraphic likeness to Tierra del Fuego, plate kinematic data show the South Georgia microcontinent as having originated at the eastern end of the North Scotia Ridge. Here, it can be envisaged as having formed part of a wide zone of mixed heritage that accreted to, or detached from and was accreted back to, west Gondwana in Paleozoic times (Pankhurst et al., 2006). Later, the island formed part of a sheared and then passive margin on the southern fringe of the Falkland Plateau as this mixed zone became the locus of the supercontinent's breakup. Later still it was transported eastwards to its present position. With such a history, the microcontinent could not have presented a proximal barrier to deep Pacific-Atlantic flow during the Eocene-onset opening of Drake Passage and is equally unlikely to have presented any serious obstacle to shallower connectivity earlier on. The passage may thus have played a role in global change starting at that time, by allowing the shallow Pacific-Atlantic current flow through which 
a shift in oceanic circulation and productivity patterns could have been initiated.

Instead, with such a placement, South Georgia would more likely have presented a long-lived barrier to northward turning currents within the Scotia Sea. In the presence of such a barrier, any deep current would have been compelled to exit the young Scotia Sea through gaps between ancestral islands and seamounts of the South Sandwich Arc, as jets of the present-day Antarctic Circumpolar Current do today. A northward turning current perhaps only recently became possible at about 17 Ma when seafloor spreading at the West Scotia Ridge slowed and a median valley appeared, effecting the opening of the Shag Rocks Passage as the ridge propagated northwards (Eagles et al., 2005). Such a sequence of events is consistent with estimates of the relatively late-onset of contourite sedimentation in the Falkland Trough (Koenitz et al., 2008), which hence need not be regarded as a primary record of the onset of the Antarctic Circumpolar Current. Having recognized this, however, the absence of any other strong evidence in the Southern Ocean for significant circumpolar flow prior to latest Oligocene times should be noted (Pfuhl and McCave, 2005). In the light of what I have shown here, it is possible to conclude that while a deep water passageway undoubtedly existed but appears not to have been utilized for circumpolar flow, this may not have been because of the presence of a physical barrier in Drake Passage, but instead because of the lack of a strong meridional temperature gradient to drive it.

\section{Acknowledgements}

I thank Royal Holloway, University of London for support. Matias Ghiglione and Bob Pankhurst both provided thought-provoking and constructive reviews for which I am very grateful.

\section{References}

Alabaster, T., Storey, B.C., 1990. Modified Gulf of California model for south Georgia, north Scotia Ridge, and implications for the Rocas Verdes back-arc basin, southern Andes. Geology 18, 497-500

Barbeau Jr., D.L., Olivero, E.B., Swanson-Hysell, N.L., Zahid, K.M., Murray, K.E., Gehrels, G.E., 2009. Detrital-zircon geochronology of the eastern Magallanes foreland basin: implications for Eocene kinematics of the northern Scotia Arc and Drake Passage. Earth Planet. Sci. Lett. 284, 489-503. doi:10.1016/ j.epsl.2009.05.014.

Barker, P.F., Dalziel, I.W.D., Dinkelman, M.G., Elliot, D.H., Gombos Jr., A.M., et al., 1977. Site 330. In: Barker, P.F., Dalziel, I.W.D. (Eds.), Initial Reports of the DeepSea Drilling Project, vol. 36. U.S. Govt. Printing Office, Washington, pp. 281-293.

Barker, P.F., Dalziel, I.W.D., Storey, B.C., 1991. Tectonic development of the Scotia Arc region. In: Tingey (Ed.), Antarctic Geology. Oxford University Press, Oxford, pp. 215-248.

Barker, P.F., 2001. Scotia Sea regional tectonic evolution: implications for mantle flow and palaeocirculation: Earth Sci. Rev., 55, 1-39.

Barron, E.J., Harrison, C.G.A., Hay, W.W., 1978. A revised reconstruction of the southern continents. EOS Trans. AGU 59, 436-449.

Bruhn, R.L., 1979. Rock structures formed during back-arc basin deformation in the Andes of Tierra del Fuego. GSA Bull. 90, 998-1012.

Burns, K.L., Richard, M.J., Belbia, L., Channelawn, F., 1980. Further paleomagnetic confirmation of the Patagonian Orocline. Tectonophysics 63, 75-90. doi:10.1016/0040-1951(80)90108-0.

Calderón, M., Fildani, A., Hervé, F., Fanning, C.M., Weislogel, A., Cordani, U., 2007. Late Jurassic bimodal magmatism in the northern sea-floor remnant of the Rocas Verdes basin, southern Patagonian Andes. J. Geol. Soc. 164, 1011-1022.

Cunningham, A.P., Barker, P.F., Tomlinson, J.S., 1998. Tectonics and sedimentary environment of the North Scotia Ridge region revealed by side-scan sonar. J. Geol. Soc. London 155, 941-956.

Cunningham, W.D., 1995. Orogenesis at the southern tip of the Americas - the structural evolution of the Cordillera Darwin metamorphic complex, southernmost Chile. Tectonophysics 244, 197-229.

Cunningham, W.D., Dalziel, I.W.D., Lee, T.-Y., Lawver, L.A., 1995. Southernmost south America-Antarctic Peninsula relative plate motions since $84 \mathrm{Ma}$ : implications for the tectonic evolution of the Scotia Arc region. J. Geophys. Res. 100, $8257-8266$.

Curtis, M.L., 2007. Main Andean sinistral shear along the Cooper Bay Dislocation zone, south Georgia? In: Cooper, A.K., Raymond, C.R., et al. (Eds.), Antarctica: A
Keystone in a Changing World - Online Proceedings of the 10th ISAES USGS Open-File Report 2007-1047, p. 4. doi:10.3133/of2007-1047.srp034.

Curtis, M.L., Flowerdew, M.J., Riley, T.R., Whitehouse, M.J., Daly, J.S., 2010. Andean sinistral transpression and kinematic partitioning in South Georgia. J. Struct. Geol. doi:10.1016/j.jsg.2010.02.002

Dalziel, I.W.D., Elliot, D.H., 1971. Evolution of the Scotia Arc. Nature 233, 246-251.

Dalziel, I.W.D., Dott Jr., R.H., Winn Jr., R.D., Bruhn, R.L., 1975. Tectonic relations of South Georgia island to the southernmost Andes. Geol. Soc. Am. Bull. 86, 1034-1040.

Dalziel, I.W.D., 1981. Back-arc extension in the Southern Andes: a review and critical reappraisal. Philos. Trans. R. Soc. Lond. A 300, 319-335.

Dalziel, I.W.D., 1982. The Early (pre-middle Jurassic) history of the Scotia Arc region - a review and progress report. In: Craddock, C. (Ed.), Antarctic Geoscience. University of Wisconsin Press, Madison, pp. 111-126.

Del Ben, A., Mallardi, A., 2004. Interpretation and chronostratigraphic mapping of multichannel seismic reflection profile I95167, Eastern Falkland Plateau (South Atlantic). Mar. Geol. 209, 347-361.

Eagles, G., Livermore, R.A., Fairhead, J.D., Morris, P., 2005. Tectonic evolution of the west Scotia Sea. J. Geophys. Res. doi:10.1029/JB2004003154.

Eagles, G., Livermore, R.A., Morris, P., 2006. Small basins in the Scotia Sea: the Eocene Drake Passage gateway. Earth Planet. Sci. Lett. 242, 343-353.

Eagles, G., Vaughan, A.P.M., 2009. Gondwana breakup and plate kinematics: business as usual. Geophys. Res. Lett. doi:10.1029/2009GL037552.

Ghidella, M.E., Yáñez, G., LaBrecque, J.L., 2002. Revised tectonic implications for the magnetic anomalies of the Western Weddell sea. Tectonophysics 347, 65-86.

Ghiglione, M.C., Cristallini, E.O., 2007. Have the southernmost Andes been curved since Late Cretaceous times? An analog test for the Patagonian Orocline. Geology 35, 13-16.

Glasser, Ghiglione, 2009. Structural, tectonic and glaciological controls on the evolution of fjord landscapes. Geomorphology 105, 291-302.

Graham, A.G.C., Fretwell, P.T., Larter, R.D., Hodgson, D.A., Wilson, C.K., Tate, A.J., Morris, P., 2008. A new bathymetric compilation highlighting extensive paleoice sheet drainage on the continental shelf, South Georgia, sub-Antarctica. Geochem. Geophys. Geosyst. 9 (Q07011). doi:10.1029/2008GC001993.

Hervé, F., Fanning, C.M., Pankhurst, R.J., 2003. Detrital zircon age patterns and provenance of the metamorphic complexes of southern Chile. J. South Am. Earth Sci. 16, 107-123.

Hervé, F., Miller, H., Pimpirev, C., 2005. Patagonia - Antarctica connections before Gondwana Break-Up. In: Fütterer, D.K., Damaske, D., Kleinschmidt, G., Miller, H., Tessensohn, F. (Eds.), Antarctica: Contributions to Global Earth Sciences. Springer-Verlag, Berlin, Heidelberg \& New York, pp. 215-226.

Hervé, F., Fanning, C.M., Pankhurst, R.J., Mpodozis, C., Klepeis, K., Calderón, M., Thomson, S., 2010. Detrital zircon SHRIMP U-Pb age study of the Cordillera Darwin Metamorphic Complex of Tierra del Fuego: sedimentary sources and implications for the evolution of the Pacific margin of Gondwana. J. Geol. Soc. London 167, 1-13.

Katz, H.R., 1963. Revision of Cretaceous stratigraphy in Patagonian cordillera of Ultima Esperanza, Magallanes province, Chile. Am. Assoc. Pet. Geol. Bull. 47, 506-524.

Kennett, J.P., Houtz, R.E., Andrews, P.B., Edwards, A.R., Gostin, V.A., Hajos, M., Hampton, M.A., Jenkins, D.G., Margolis, S.V., Ovenshine, A.T., Perch-Nielsen, K., 1975. In: Kennett, J.P., Houtz, R.E., et al. (Eds.), Cenozoic paleoceanography in the southwest Pacific Ocean, Antarctic glaciation and the development of the Circum-Antarctic current. Init. Rep. DSDP, vol. 29. US Govt. Printing Office, Washington, pp. 1155-1169.

Koenitz, D., White, N., McCave, I.N., Hobbs, R., 2008. Internal structure of a contourite drift generated by the Antarctic circumpolar current. Geochem. Geophys. Geosyst. 9 (Q06012). doi:10.1029/2007GC001799.

Kraemer, P.E., 2003. Orogenic shortening and the origin of the Patagonian orocline (56 degrees S. Lat). J.S. Am. Earth Sci. 15, 731-748.

Kraemer, P.E., Riccardi, A.C., 1997. Estratigrafía de la región comprendida entre los lagos Argentino y Viedma $\left(49^{\circ} 40-50^{\circ} 10\right.$ lat. S), Provincia de Santa Cruz, Asoc. Geol. Arg. Rev. 52, 333-360.

Kristoffersen, Y., Haugland, K., 1986. Geophysical evidence for the east Antarctic plate boundary in the Weddell sea. Nature 322, 538-541.

Kristoffersen, Y., LaBrecque, J., 1991. On the tectonic history and origin of the Northeast Georgia Rise. In: Ciesielski, P.F., Kristoffersen, Y., et al. (Eds.), Proc. ODP, Sci. Results, 114: College Station, TX (Ocean Drilling Program), pp. 23-38. doi:10.2973/odp.proc.sr.114.173.1991.

Ludwig, W.J., Rabinowitz, P.D., 1982. The collision complex of the north Scotia Ridge. J. Geophys. Res. 87, 3731-3740.

Marks, K.M., Stock, J.M., 2001. Evolution of the Malvinas Plate south of Africa. Mar. Geophys. Res. 22, 289-302.

Maffione, M., Speranza, F., Faccenna, C., Rossello, E., 2009. Paleomagnetic evidence for a pre-early Eocene ( $\sim 50 \mathrm{Ma}$ ) bending of the Patagonian orocline (Tierra del Fuego, Argentina): paleogeographic and tectonic implications. Earth Planet. Sci. Lett. 289, 273-286. doi:10.1016/j.epsl.2009.11.015.

Menichetti, M., Lodolo, E., Tassone, A., 2008. Structural geology of the Fuegian Andes and Magallanes fold and thrust belt - Tierra del Fuego island. Geol. Acta 6, 19-42. doi:10.1344/105.000000239.

Millar, I.L, Pankhurst, R.J., Fanning, C.M., 2002. Basement chronology of the Antarctic Peninsula: recurrent magmatism and anatexis in the Palaeozoic Gondwana margin. J. Geol. Soc. London 159, 145-157. doi:10.1144/0016-764901-020.

Mukasa, S.B., Dalziel, I.W.D., 1996. Southernmost Andes and South Georgia island, North Scotia Ridge: zircon $\mathrm{U}-\mathrm{Pb}$ and muscovite ${ }^{40} \mathrm{Ar} /{ }^{39} \mathrm{Ar}$ age constraints on 
tectonic evolution of southwestern Gondwanaland. J. South Am. Earth Sci. 9, 349-365.

Pandey, A., Parson, L., Milton, A. Geochemistry of the Davis and Aurora Banks: possible implications on evolution of the North Scotia Ridge. Marine Geology, 268, 106-114, doi:10.1016/j.margeo.2009.10.025.

Pankhurst, R.J., Leat, P.T., Sruoga, P., Rapela, C.W., Márquez, M., Storey, B.C. Riley, T.R., 1998. The Chon Aike silicic igneous province of Patagonia and related rocks in Antarctica: a silicic large igneous province. J. Volcan. Geotherm. Res. 81, $113-136$

Pankhurst, R.J., Rapela, C.W., Fanning, C.M., Márquez, M., 2006. Gondwanide continental collision and the origin of Patagonia. Earth-Sci. Rev. 76, 235-257.

Pankhurst, R.J., Rapela, C.W., 1995. Production of Jurassic rhyolite by anatexis in the lower crust of Patagonia. Earth Planet. Sci. Lett. 134, 23-36.

Pelayo, A.M., Wiens, D.A., 1989. Seismotectonics and relative plate motions in the Scotia Sea region. J. Geophys. Res. 94, 7293-7320.

Pfuhl, H.A., McCave, I.N., 2005. Evidence for late Oligocene establishment of the Antarctic Circumpolar Current. Earth Planet. Sci. Lett. 235, 715-728.

Riley, T.R., Millar, I.L., Watkeys, M.K., Curtis, M.L., Leat, P.T., Klausen, M.B., Fanning, C.M., 2004. U-Pb zircon (SHRIMP) ages for the Lebombo rhyolites, South Africa: refining the duration of Karoo volcanism. J. Geol. Soc. London 161, 547-550. doi:10.1144/0016-764903-181.

Schilling, M.E., Carlson, R.W., Conceição, R.V., Dantas, C., Bertotto, G.W., Koester, E., 2008. Re-Os isotope constraints on subcontinental lithospheric mantle evolution of southern South America. Earth Planet. Sci. Lett. 268, 89-101.
Stern, C.R., 1991. Isotopic composition of late Jurassic and early Cretaceous mafic igneous rocks from the southernmost Andes: implications for sub-Andean mantle. Revista Geológica de Chile 18, 15-23.

Stern, C.R., de Wit, M.J., 2003. Rocas Verdes ophiolites, southernmost South America: remnants of progressive stages of development of oceanic-type crust in a continental margin back-arc basin, vol. 218. Geol. Soc. London Spec. Pub., pp. 665-683.

Storey, B.C., Mair, B.F., Bell, 1977. The occurrence of Mesozoic oceanic floor and ancient continental crust on South Georgia. Geol. Mag. 114, 203-208.

Storey, B.C., Mair, B.F., 1982. The composite floor of the Cretaceous back-arc basin of South Georgia. J. Geol. Soc. London 139, 729-737.

Storey, B.C., Tanner, P.W.G., 1982. Geochemistry of a Mesozoic island-arc assemblage and ocean floor basalts from South Georgia. Bull. Brit. Ant. Surv. 56, 7-24.

Storey, B.C., Macdonald, D.I.M., 1984. Processes of formation and filling of a Mesozoic back-arc basin on the island of South Georgia. In: Kokelaar, B.P., Howells, M.F. (Eds.), Marginal Basin Geology. Geol. Soc. Lond. Spec. Pub, 16, pp. 207-218.

Tanner, P.W.G., Rex, D.C., 1979. Timing of events in an Early Cretaceous Island arc marginal basin system on South Georgia. Geol. Mag. 116, 167-179.

Tassone, A., Lodolo, E., Menichetti, M., Yagupsky, D., Caffau, M., Vilas, J.F., 2008. Seismostratigraphic and structural setting of the Malvinas Basin and its southern margin (Tierra del Fuego Atlantic offshore). Geol. Acta 6, 55-67. doi:10.1344/105.000000241.

Thomas, C., Livermore, R.A., Pollitz, F.F., 2003. Motion of the Scotia Sea Plates. Geophys. J. Int. 155, 789-804.

Winn Jr., R.D., 1978. Upper Mesozoic flysch of Tierra del Fuego and South Georgia island: a sedimentologic approach to lithosphere plate restoration. GSA Bull. 89, 533-547. 